\title{
Leech (Limnatis nilotica) causing respiratory distress in a pregnant cow in Ilam province in Iran
}

\author{
Mahmoud Bahmani • Zohre Eftekhari • \\ Ava Mohsezadeghan • Freidon Ghotbian • \\ Nafise Alighazi
}

Received: 13 November 2010 /Accepted: 5 April 2011 /Published online: 20 May 2011

(C) Springer-Verlag London Limited 2011

\section{Introduction}

Leeches, a hermaphroditic, blood-sucking parasite are rarely reported in humans and animals as a cause of many problems. They vary in color, length and shape, and may be black, brightly colored, or mottled. The leeches mainly inhabit in ponds, lakes, and streams. The Limnatis nilotica species is a blood-sucking parasite that lives in stagnant water in ponds and lakes. The strong jaws and muscular suckers at the anterior and posterior ends of $L$. nilotica are the main sign for detection. This species is commonly found existing in Southern Europe, North Africa, and the Middle East including Iran (Bahmani et al. 2006). These leeches live in hosts and can cause anemia and may act as vectors of animal pathogens. The main symptoms include haemoptysis, snoring, dyspnea, cough, dysphagia, and bleeding from the vagina (Bani Ismail et al. 2007; Estambale et al. 1992; Grosser and Pesic 2006; Yaghmaee 2000). Hirudiniasis is not common in animal and human, but sporadic reports of leech infestations in humans and animals are available from the Middle East and adjoining countries. In some reports in human beings, leeches as a foreign body and parasite in the respiratory tract have been reported, and in animals, leeches infesting the nasal cavity were reported in one camel in Iraq (Al-Ani and Al-Shareefi 1995; Cheikh-Rouhou et al. 2000). In this study, a 3-year-old pregnant cow referred to a private clinic in the

\footnotetext{
M. Bahmani

Shahrekord University,

Shahrekord, Iran

Z. Eftekhari $(\bowtie) \cdot$ A. Mohsezadeghan $\cdot$ F. Ghotbian $\cdot$ N. Alighazi

Tehran University,

Tehran, Iran

e-mail: z_eftekhari.vet@ut.ac.ir
}

Dehloran suburbs in Iran with acute respiratory distress and inappetite.

\section{Case report}

A 3-year-old pregnant cow referred to a private clinic in the Dehloran suburbs in Iran with acute respiratory distress and inappetite. The history of the case revealed that the main feed of the cow had been hay and grazing in pasture, and for drinking water, a stream and sump were used $48 \mathrm{~h}$ previous to the time of referral; the cow displayed severe discomfort, with little appetite, abnormal breathing, and respiratory sounds. The case had no background of any disorder. Examination of the case showed increasing respiratory rates, bleeding from the mouth, and reluctance to walk.

The temperature, heart rate, and respiratory rate were increased slowly. Rectal examination manifested no abnormal signs and the fetus palpated and was alive. The mouth of the cow was fully opened, and the mouth cavity was fully explored. One leech was found attached to the right-side cheek and tongue (Fig. 1). The leeches were removed by using forceps carefully without the prescription of any drugs, and after examination, the species of leech was identified as L. nilotica. The strong jaws and muscular suckers at the anterior and posterior ends, the dark-green color surface with rows of green spots on the dorsal surface, and yellowish-orange and dark-green bands on either side with a 100-mm length were the main signs for detection of $L$. nilotica species. Investigations revealed that the animal used to drink water from a nearby pond that had rainwater. The owner of the present case was educated not to allow the other animals to drink water from the infested pond. 


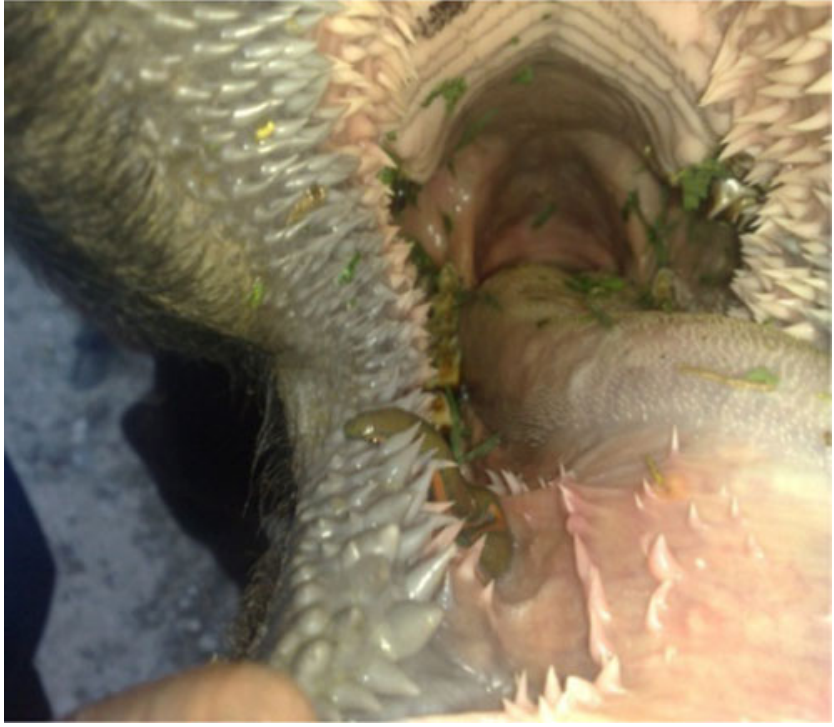

Fig. 1 Limnatis nilotica was found attached to the right-side cheek and tongue

After the final diagnosis of hirudiniasis, a 10 -cc blood sample (without the coagulative substance) and a 2-cc blood sample for complete blood cell count (CBC) were taken from the jugular vein of the cow and sent to the laboratory, where the samples were centrifuged at $3,000 \mathrm{rpm}$ for $10 \mathrm{~min}$. When the serum samples were ready, the serum biochemical profiles were done. The serological data and $\mathrm{CBC}$ are shown in Table 1.

CBC results showed mild anemia (normocyctic, normochromic) with mild leukocytosis and neutrophilia. Red blood cell counts (RBCs) and (hemoglobin) $\mathrm{Hb}$ were below the normal range, but PCV as well as the serological data were within the normal ranges (Table 2).

Table 1 CBC of affected cow

\begin{tabular}{llll}
\hline Parameter & & Normal & Value \\
\hline $\mathrm{PVC}$ & $\%$ & $24-46$ & 21 \\
$\mathrm{Hb}$ & $\mathrm{g} / \mathrm{dl}$ & $8-15$ & 6.5 \\
$\mathrm{RBC}$ & $\times 10^{6} / \mu \mathrm{l}$ & $5-10$ & 4.84 \\
$\mathrm{MCV}$ & $\mathrm{fL}$ & $40-60$ & 42 \\
$\mathrm{MCH}$ & $\mathrm{pg}$ & $11-17$ & 12.7 \\
$\mathrm{MCHC}$ & $\mathrm{g} / \mathrm{dL}$ & $30-36$ & 30.9 \\
$\mathrm{WBC}$ & $\times 10^{9} / \mathrm{L}$ & $4-12$ & 4.2 \\
$\mathrm{Neut}$. band & $\times 10^{9} / \mathrm{L}$ & $0.0-0.1$ & 0.134 \\
Neut. seg & $\times 10^{9} / \mathrm{L}$ & $0.6-4$ & 5.67 \\
Lymphocyte & $\times 10^{9} / \mathrm{L}$ & $2.5-7.5$ & 3.54 \\
Monocyte & $\times 10^{9} / \mathrm{L}$ & $0.0-0.9$ & 0.234 \\
Eosinophile & $\times 10^{9} / \mathrm{L}$ & $0.0-2.4$ & 0.0 \\
Platelets & $\times 10^{9} / \mu \mathrm{l}$ & $100-800$ & 213 \\
& & & \\
\hline
\end{tabular}

Table 2 Serological parameters

\begin{tabular}{llll}
\hline Parameter & & Normal range & Value \\
\hline TP (total protein) & $\mathrm{g} / \mathrm{dl}$ & $6.7-7.5$ & 7.2 \\
Albumin & $\mathrm{g} / \mathrm{dl}$ & $2.5-3.8$ & 2.7 \\
Glucose & $\mathrm{mg} / \mathrm{dl}$ & $40-100$ & 69 \\
Creatinine & $\mathrm{mg} / \mathrm{dl}$ & $0.5-2.2$ & 1.2 \\
Magnesium & $\mathrm{mg} / \mathrm{dl}$ & $1.5-2.9$ & 1.7 \\
AST & $\mathrm{U} / \mathrm{L}$ & $60-125$ & 112 \\
BUN & $\mathrm{mg} / \mathrm{dl}$ & $10-25$ & 15 \\
Phosphorus & $\mathrm{mg} / \mathrm{dl}$ & $5.6-8$ & 6.7 \\
Calcium & $\mathrm{mg} / \mathrm{dl}$ & $8-11.4$ & 10 \\
\hline
\end{tabular}

\section{Discussion}

Leeches, a blood-sucking parasite, are rarely reported in humans and animals as a cause of many problems. Hirudiniasis is not common in animal and humans; however, sporadic reports of leech infestations in humans and animals are available from the Middle East and adjoining countries. In some reports in human beings, leeches as a parasite in the respiratory tract have been reported, and in animals, leeches infesting the nasal cavity were reported in one camel in Iraq (Al-Ani and Al-Shareefi 1995; Cheikh-Rouhou et al. 2000). The first reported infestation in sheep of L. nilotica in Iran was reported by Bahmani et al. (2006), in which six to seven leeches were isolated from the esophagus. The hemathological signs showed normocyctic normochromic anemia that were the same as the presented case. Some reports from Elam province in Iran have shown L. nilotica in sheep, cattle, dog, and donkey, all of which manifested respiratory disorders and anemia (Mehrzad et al. 2007). Mehrzadi et al. (2009) reported an infestation of L. nilotica in herd dog in Shahrekord province in Iran. That particular case showed $3 \%$ anemia and local acute infestation. Another report of $L$. nilotica was from a 4-year-old cow with acute respiratory distress and continuous profuse bleeding from both nostrils. After removing the leeches from the nostrils and maintaining supportive treatment, the animal died after a few hours (Moghaddar 2010). In this case, however, the leeches were removed carefully by using forceps without the prescription of any drugs. After examination, the species of leech was identified as L. nilotica.

Cundall et al. in 1986 reported laryngeal leeches (Myxobdella africana) in six infants with severe anemia, one of whom died due to severe anemia. The strong jaws and muscular suckers at the anterior and posterior ends can suck the blood of hosts, and this can cause anemia. Stickland et al. in 2000 mentioned that leeches could suck the blood of hosts nine times more than the size of their 
bodies. They secrete an anticoagulant substance containing hirudin, which inhibits the thrombin, factor IXa, and other enzymes (Will 1988). These anticoagulants enable the leech to feed on its host freely. The saliva of leeches contains enzymes and anti-auglutination substances such as hirodine, antielastaze, antitripsine, and antiplasmine, which cause bleeding and anemia (El-Awad and Patil 1990).

Occasionally, for removing the leeches in humans and dogs, a local or systemic anesthesia is used by using lidocaine $1 / 10,000$, cocaine $30 \%$, diethylphtalate, sulfate atropine $(0.04 \mathrm{mg} / \mathrm{kg})$, xilazyne HCL, and ketamine HCL. In the present case, however, a gag was used to remove the leech without using any anesthesia (Uygur et al. 2003; Bani Ismail et al. 2007).

Although some of the literature mentioned that after removing the leeches prescribing ferrous sulfate could help to relieve anemia; in this case, no medication was prescribed (Bani Ismail et al. 2007; Haycox et al. 1995).

The majority of inhabitances of leeches are ponds, lakes, and streams (Mohammad et al. 2002). After the intake of contaminated water, the leech is localized in the upper respiratory system or digestive system. These locations are mostly the nose, nasopharynx, oropharynx, epiglottis, larynx, and upper trachea. Investigations revealed that the animal used to drink water from a nearby pond that had rainwater. The owner of the present case was educated not to allow the other animals to drink water from the infested pond.

\section{References}

Al-Ani FK, Al-Shareefi MR (1995) Observation on medical leech (Limnatis nilotica) in camel in Iraq. Journal of Camel Practice and Research 2(2):145

Bahmani M, Zamani P, Meshgi B, Abdi Zadeh R (2006) The first reported infestation in sheep at Limnatis nilotica in Iran, Sixth National Conference and the first Regional Congress of Parasitology and Parasitic Diseases, 7-9 June, Karaj, p 384
Bani Ismail ZA, Al- Majali A, Ababneh H, Al-Omari (2007) Laryngeal leeches causing exercise intolerance, respiratory distress and hemoptysis in a hunting dog. The Internet Vet Med 3(1)

Cheikh-Rouhou F, Besbes M, Makni F, Chaabouni M, Ayadi A (2000) Limnatis nilotica, cause of severe anaemia in an infant. Med Trop (Mars) 60:100-101

Cundall DB, Whitehead SM, Hechtel FO (1986) Severe anemia and death due to the pharyngeal leech, Myxobdella africana. Trans R Soc Trop Med Hyg 80:940-944

El-Awad ME, Patil K (1990) Haemotemesis due to leech infestation. J Ann Trop Paediatr 10(1):61-62

Estambale BB, Knight R, Chunge R (1992) Haematemesis and severe anaemia due to a pharyngeal leech (Myxobdella africana) in a kenyan child: a case report. Trans $\mathrm{R}$ Soc Trop Med Hyg 86:458

Grosser C, Pesic V (2006) On the diversity of Iranian leeches (Annelida: Hirudinea). Arch Biol Sci, Belgrade 58(i):21-24

Haycox CL, Odland PB, Clotrea MD, Raugi GJ (1995) Indications and complications of medicinal leach therapy. J Am Acad Dermatol 33:1053-1055

Mehrzad S, Razi Jalali MH, Bahmani M, Rahbar A (2007) Report infestation of Limnatis nilotica (leech) in sheep, cattle, dogs and donkeys in the city of Dehloran. Sixth National Conference Veterinarians Clinical Sciences, Islamic Azad University of Tabriz, 6-8 August, p 648

Mehrzadi S, Razi Jalali MH, Bahmani M, Rahbar A. [Reports infestation of Limnatis nilotica (leech) in sheep, cattle, dogs and donkeys in the city of Dehloran. Sixth National Conference Veterinar Clin Sci. Islamic Azad University of Tabriz. TabrizIran. 2009 6-8 Aug; p: 648.] Persian

Moghaddar N (2010) Fatal hirudiniasis in a cow. Comp Clin Path. doi:10.1007/s00580-010-0969-6

Mohammad Y, Rostum M, Dubaybo BA (2002) Laryngeal hirudiniasis: an unusual cause of airway obstruction and hemoptysis. Pediatr Pulmonol 33:224-226

Stickland G (2000) Hunter's tropical medicine and emerging infectious disease, 8th edn. W.B. Saunders Company, Philadelphia, p 895

Uygur K, Yasan H, Yavuz L, Dogru H (2003) Removal of a laryngeal leech: a safe and effective method. Am J Otolaryngol 24:338-340

Will RB (1988) Hirudin and the role thrombin: lessons from leeches. Trends Pharmacol Sci 9:425-427

Yaghmaee M (2000) An abnormal vaginal bleeding at causes of leech. Zahedan J Res Med Sci 3(1):41-43 